\title{
近世京都における絵師の居住傾向 THE TENDENCY OF THE PAINTERS' ADDRESS \\ IN THE EARLY MODERN PERIOD IN KYOTO
}

\author{
安 道 永* \\ Michinaga $A H N$
}

\begin{abstract}
The purpose of this study is to solve the tendency of the painters' address in the early modern period in Kyoto. The results are as follows: (1) Painters lived particular streets from Tenmei period. intensive streets were Nizyo-dori, Sizyo-dori, Sanzyo-dori, and Marutamati-dori from Bunka period downward. (2) They lived particular areas from Bunsei period. (3) The number of painters lived south of Sizyo-dori increased from Koka period. (4) The number of painters lived south of Imperial palace increased from Koka period. (5) Many painter, belong to Bunzingaka, Sizyo school, and Kisi school, lived surround Gion, Syogoin village, Hyakumanben, Okazaki village, and Fusimi.
\end{abstract}

Keywords : Painters, Early modern period, Kyoto, Imperial palace, Suburb 絵師，近世，京都，内裏，郊外

\section{1.はじめに}

本稿の目的は、近世京都における絵師の居所について、その実態 を解明する端緒として、年代をおって居住分布の傾向を解明するこ とにある。

近世京都では様々な人名録が発行されたが、本稿では、『平安人物 志』注 1)、『皇都書画人名録』注 2)、『京羽二重』注 3)、『京羽津根 (京 洛羽津根)』注4)使用した。これらに収録される絵師の名前・流派・ 居所を抽出し、年代順に絵師の居住分布の傾向を看取する注5)。

先の人名録において、『平安人物志』が近年注目されている注 6)。 並木誠士氏は、特定できる絵師の居所を東西筋と南北筋に分解して、 その頻度を抽出することで、東西筋では四条通が、南北筋では室町 通がもつとも頻度が高いと指摘し、さらに、『平安人物志』9版の中 で絵師の居所についてはそれほど大きな変化は見られない、と結論 付けている注 7)。田島達也氏は、『平安人物志』を配列・順位の問題 に注目し、画家および画壇という視点から検討した注8)。武智正晃氏 は、『平安人物志』に収録される人物に関する必要最低限の情報把握 を目的とし、データベースを作成した注9)。絵師以外の職種では、久 保智康氏は錺師に注目し、居住分布図を作成した注 10)。このように、 絵師の居所については、すでに多くのデータが公開されている。こ れらを踏まえて、並木氏は絵師の居所に関する傾向を論じたが、近 世における傾向を総括したものであり、近世のいつ頃からその傾向 が現れたのか言及されず精細さを欠く。そこで本稿では、新たな史 料を加えつつ、公開されているデータを再整理し、これまで作成さ れた居住分布図より、詳細な居住分布図を作成し、もって絵師の居 住分布について、その傾向をおっていく。

\section{2.『平安人物志』、『皇都書画人名録』、『京羽二重』、『京羽津根（京 洛羽津根)』について}

『平安人物志』は、明和 5 年 (1768)、安永 4 年 (1775)、天明 2 年 $(1782) 、$ 文化 10 年 (1813)、文政 5 年 $(1822) 、$ 文政 13 年 $(1830) 、$ 天保 9 年 (1838)、嘉永 5 年 (1852)、慶応 3 年 (1867) の計 9 版発 行された。発行元は京都の博昌堂と芸香堂である。『皇都書画人名録』 は、弘化 4 年（1847）の序があるが、奥付に発行年は記されていな い。発行元は順祥堂ほかである。『京羽二重』は、貞享 2 年 (1685)、 宝永 2 年（1705）に発行された。延享 2 年（1745）に増補して『京 羽二重大全』となり、明和 5 年（1768）、天明 4 年 (1784)、文化 8 年 (1811) に発行された。『京羽津根 (京洛羽津根)』は、『京羽二重』 と『京羽二重大全』の流れを引き継ぎ、文久 3 年 (1863)、元治元年 (1864)、慶応元年 $(1865) 、$ 慶応 3 年 (1867)、明治 4 年 (1871) に 発行された。

表 1 本稿で使用した人名録における絵師の収録数

\begin{tabular}{|c|c|c|c|c|c|c|}
\hline & \multirow[t]{2}{*}{ 収録数 } & \multicolumn{3}{|c|}{ 居所記載 } & \multirow[t]{2}{*}{ 居所不記載 } \\
\hline & & & 居所特定 & 他国に遊事 & 居所不特定 & \\
\hline 京羽二重 & 貞享2年版(1685) & 5 & 4 & 0 & 1 & 0 \\
\hline 平安人物志 & 明和5年版(1768) & 16 & 14 & 0 & 1 & 1 \\
\hline 平安人物志 & 安永4年版(1775) & 20 & 17 & 1 & 0 & 2 \\
\hline 平安人物志 & 天明2年版(1782) & 29 & 27 & 0 & 1 & 1 \\
\hline 平安人物志 & 文化10年版(1813) & 93 & 82 & 0 & 1 & 10 \\
\hline 平安人物志 & 文政5年版(1822) & 117 & 101 & 5 & 1 & 10 \\
\hline 平安人物志 & 文政13年版(1830) & 163 & 149 & 4 & 4 & 6 \\
\hline 平安人物志 & 天保9年版(1838) & 137 & 122 & 2 & 8 & 5 \\
\hline 平安人物志 & 嘉永5年版(1852) & 147 & 136 & 0 & 5 & 6 \\
\hline 平安人物志 & 慶応3年版(1867) & 102 & 94 & 0 & 2 & 6 \\
\hline 皇都書画人名録 & 弘化4年版(1847) & 246 & 230 & 1 & 12 & 3 \\
\hline 京羽津根 & 文久3年版（1863） & 15 & 15 & 0 & 0 & 0 \\
\hline
\end{tabular}

\footnotetext{
*関西大学大学院工学研究科 博士後期課程 修士 (工学) Graduate Student, Graduate School of Engineering, Kansai Univ.
} 
表 2 本稿で使用した人名録における絵師一覧
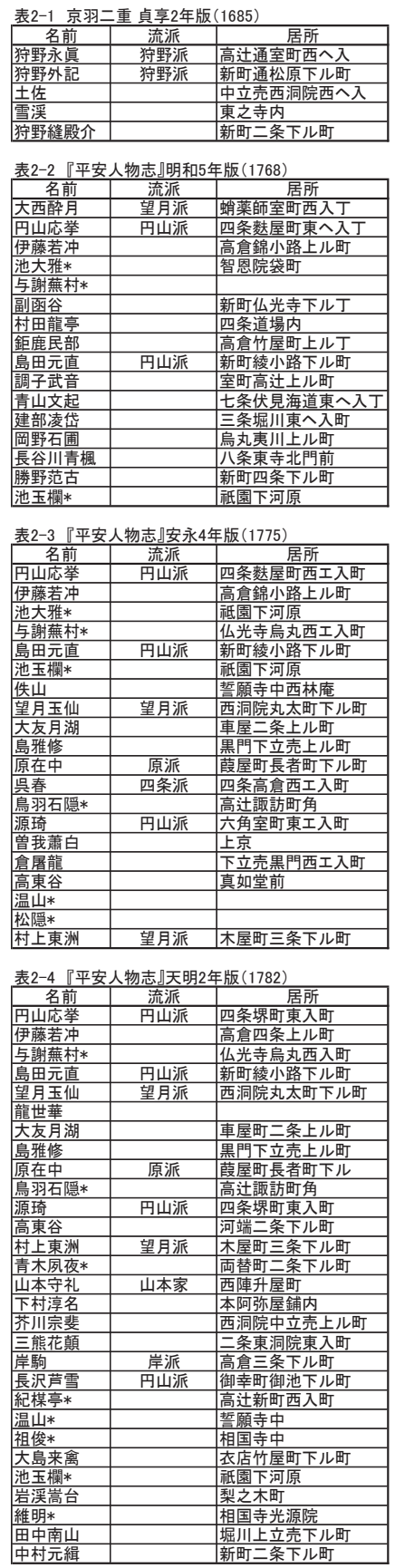

表2-5『平安人物志 』文化 10 年版 (1813)

\begin{tabular}{|c|c|c|}
\hline 多前 & & \\
\hline 土佐光時 & $\begin{array}{l}\text { 流派 } \\
\text { 土佐派 }\end{array}$ & \begin{tabular}{|l|l|} 
居所 \\
寺町丸太町
\end{tabular} \\
\hline 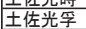 & 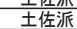 & 前人隣 \\
\hline 崔鳥沢探泉 & 鶴沢派 & 油小路竹屋町南 \\
\hline 鶴沢探春 & 鶴沢派 & \\
\hline 狩野永俊 & 狩野派 & 一条室町西 \\
\hline 山本探淵 & 鶴沢派 & 寺町五条北 \\
\hline 岸駒 & 岸派 & 間之町竹剭町北 \\
\hline 岸岱 & 岸派 & 東洞院竹豦町北 \\
\hline 勝山琢眼 & 勝山家 & 新烏丸切通 \\
\hline 勝山琢文 & 勝山家 & \\
\hline 五山応瑞 & 円山派 & 姉小路両替町西 \\
\hline 円山応震 & 円山派 & \\
\hline 東東洋 & & 柳馬場御池南 \\
\hline 東東寅 & & \\
\hline 原在中 & 原派 & 聖護院村 \\
\hline 原在明 & 原派 & 中立売室町東 \\
\hline 梅戸在親 & 原派 & \\
\hline 原在善 & 原派 & \\
\hline 吉村蘭洲 & 丹山派 & 西洞院松原南 \\
\hline 岌村孝敬 & 円山派 & \\
\hline 䓀村孝章 & 捅山派 & 同前(西洞院松原南) \\
\hline 山口素絈 & 円山派 & 祗園袋町 \\
\hline 村上東洲 & 望月派 & 新町今出川北 \\
\hline 田中訥言 & 土佐派 & 伏見街道 \\
\hline 余田如水 & 四条派 & 峏替町押小路北 \\
\hline 岡本豊彦 & 四条派 & 四条東洞院東 \\
\hline 西村楠亭 & P山派 & 新町仏光寺南 \\
\hline 河村文凰 & 岸派 & 釜座夷川北 \\
\hline
\end{tabular}

\begin{tabular}{|c|c|c|}
\hline 河村琦凰 & 岸派 & \\
\hline 石田友汀 & 鶴沢派 & 不明門雪踏屋町 \\
\hline 狩野永章 & 狩野派 & 東洞院三条北 \\
\hline 島田元直 & 円山派 & 蛤御門前 \\
\hline 高嶋千春 & & 錦小路高倉西 \\
\hline 八田古秀 & 円山派 & 副小路姉小路南 \\
\hline 上田耕夫 & 円山派 & 歁園南 \\
\hline 䂞下岕受 & 円山派 & 两替町姉小路北 \\
\hline 松村景文 & 四条派 & 四条富小路西 \\
\hline 奥文鳴 & 円山派 & 四条堺町東 \\
\hline 山跡鶴嶺 & 円山派 & 鳥丸四条北 \\
\hline 櫎山華山 & 岸派 & 笹屋町 \\
\hline 村上松堂 & 岸派 & 錦小路西洞院東 \\
\hline 長沢芦洲 & P山派 & 柳馬場四条北 \\
\hline 並河源章 & 円山派 & 四条高倉西 \\
\hline 步島来章 & 円山派 & \\
\hline 小田海供 & 四条派 & 四条烏丸西 \\
\hline 下河辺玉絃 & 土佐派 & 室町四条南 \\
\hline 佐々木大寿 & $\begin{array}{l}\text { 円山派 } \\
\end{array}$ & 四条堺町東 \\
\hline 唓岡規礼 & 山本家 & 大宮元䛚原願寺南 \\
\hline 知野夜潮 & 円山派 & 姉小路大宮東 \\
\hline 土岐済美 & 円山派 & 葦屋町上中立売北 \\
\hline 橘公順 & P山派 & 押小路間之町東 \\
\hline 紀広成 & 四条派 & 四条高倉東 \\
\hline 佐久間草偃 & 四条派 & 堺町四条北 \\
\hline 览脇有景 & 土佐派 & 御幸町御池南 \\
\hline 麻上直察 & 土佐派 & 神泉苑町 \\
\hline 㔖賀文麗 & 望月派 & 白川側梅宮町 \\
\hline 竹内重方 & 鶴沢派 & 岶万遍屋鋪 \\
\hline 世古鶴著 & & 聖護院村 \\
\hline 秀雪亭 & 丹山派 & 諁訪町松原北 \\
\hline 地方寛柔 & & 仏光寺柳馬場西 \\
\hline 三宅重見 & & 上岡崎村 \\
\hline 三宅意誠 & & 今出川小川東 \\
\hline 三橋直興 & & 油小路夷川北 \\
\hline 湧村義貞 & & 冨小路御池北 \\
\hline 三谷五雲 & 円山派 & 岶万遍屋鋪 \\
\hline 西村中和 & & 佉光寺烏丸九西 \\
\hline 別所東溪 & 四条派 & 富小路三条北 \\
\hline 高倉在孝 & 原派 & 六軒町一助北 \\
\hline 㕅村雪堂 & & 木屋町二条南 \\
\hline 山口正隣 & 円山派 & 衣棚出水南 \\
\hline 村田俊 & & 堺町三条北 \\
\hline 雄楿旭嶺 & & 柳馬場二条北 \\
\hline 度辺良景 & & 稫小路押小路南 \\
\hline 鳥羽石隠* & & 高辻諏訪町 \\
\hline 中林竹洞 $*$ & & 衣棚三条南 \\
\hline 浦上玉堂* & & 柳馬場二条北 \\
\hline 浦上春琴* & & \\
\hline 山山崎文軒* & & 車屋町二条北 \\
\hline 世継希僊* & P山派 & 三条高倉西 \\
\hline 福井応周* & & 鳥丸御池北 \\
\hline 露木露珍* & & 室町綾小路南 \\
\hline 中嶋庚嶺* & & 西洞院中立売南 \\
\hline 佐藤蘿月* & & 堺町松原北 \\
\hline 西谷管城城* & & 高倉蛸薬師南 \\
\hline 旭応 $*$ & & 東山永観堂 \\
\hline 玉潾* & & 同前 (東山永観堂) \\
\hline 月峰* & & 東山双林寺 \\
\hline 掌* & & 双林寺門前 \\
\hline 堂* & & 紫野大德寺中 妙乗 \\
\hline 護法* & & 寺町蛸薬師南 \\
\hline 月亭* & & 西洞院万寿寺 \\
\hline 南瞑* & & 鳥丸三条南 \\
\hline 玉慍* & & 東福寺中 \\
\hline
\end{tabular}
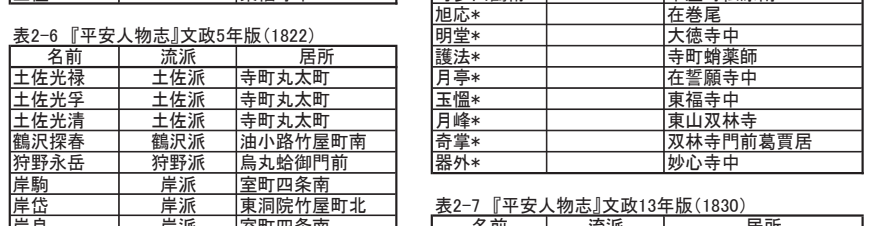

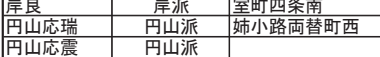

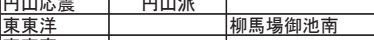

\begin{tabular}{|l|l|l|}
\hline 㡷東寅 & & \\
\hline 原在中 & 原派 & 小川中立売北 \\
\hline 原在明 & 原派 & 中立売室町東 \\
\hline
\end{tabular}

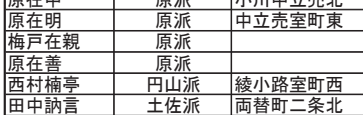

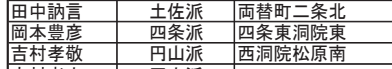

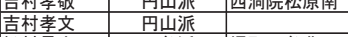

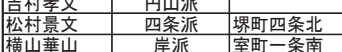

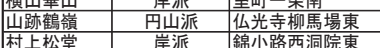

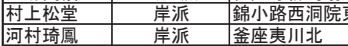

\begin{tabular}{|l|l|l}
\hline 上四夫耕夫 & 円山派 & 南禅寺傍 \\
\hline 長芦洲 & 円山山派 & 柳馬場四条北 \\
\hline
\end{tabular}

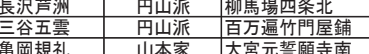

\begin{tabular}{|l|l|l|} 
嶑岡規礼 & 山本家 & 大宮元誓願寺南 \\
\hline 矢野夜潮 & 円山派 & 四条堺町東
\end{tabular}

\begin{tabular}{|l|l|l|}
\hline 矢野夜潮 & 月山派 & 四条堺町果 \\
\hline 高嶋干春 & & 遊江郡 \\
\hline
\end{tabular}

\begin{tabular}{llll} 
小田海僊 & 四条派 & 需替町二条南 \\
\hline
\end{tabular}

\begin{tabular}{|l|l|l|}
\hline 紀広成 & 四条派 & 馐替峨天龍寺傍 \\
\hline
\end{tabular}

\begin{tabular}{|l|l|l|}
\hline 甲賀文麗 & 望月派 & 白川側梅宮町 \\
\hline 竹内重方 & 鶴沢派 & 百方遍竹門屋鋪 \\
\hline
\end{tabular}

\begin{tabular}{|l|l|l}
\hline 橋直興 & 鶴沢派 & 百万遍竹門屋鋪 \\
\hline & 油小路夷川北 \\
\hline
\end{tabular}

\begin{tabular}{|l|l|l} 
& & 豈町一条南 \\
\hline 字隆 & 四条派 & 畹小路三条南 \\
\hline
\end{tabular}

\begin{tabular}{l|c|c|} 
別所東溪 & 四条派 & 富小路三条南 \\
\hline 倉在孝 & 原派 & 六軒町一条北
\end{tabular}

\begin{tabular}{|l|l|l}
\hline 村雪掌 & & 新椹木町丸太町南 \\
\hline 衣棚出水南
\end{tabular}

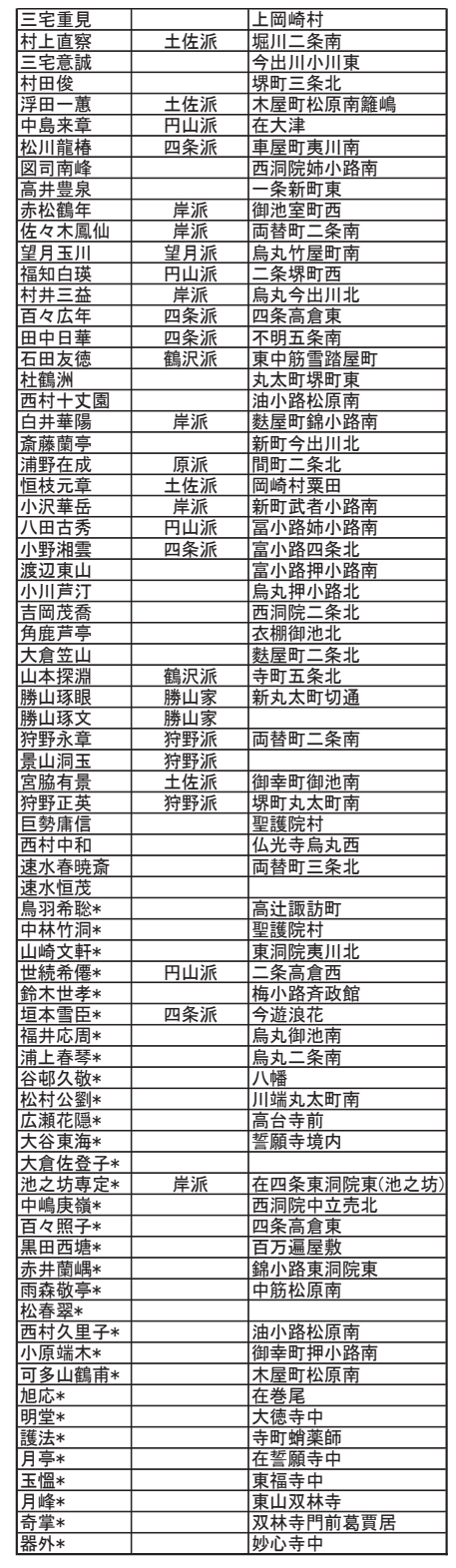

表2-7『平安人物志』文政13年版(1830)

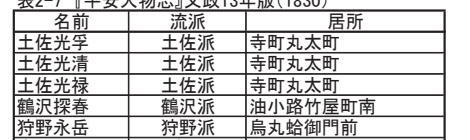

\begin{tabular}{l|l|l} 
岸駒 & 岸派 & 在北岩倉 \\
\hline
\end{tabular}

\begin{tabular}{|l|c|c|}
\hline 岸岱 & 岸派 & 東洞院竹屋町北 \\
\hline 岸慶 & 岸派 & 東洞院竹屋町北 \\
\hline 岸良 & 岸派 & 室町四条南 \\
\hline 崖連山 & 岸派 & 勇北山
\end{tabular}

\begin{tabular}{|l|l|}
\hline 東東洋 & 両替町御池北 \\
\hline 東東寅 & 耐替町御池北 \\
\hline
\end{tabular}

原在中派少川中立声比

\begin{tabular}{|l|l|l|}
\hline 原在明 & 原派 & 中立売室町東 \\
\hline 梅戸在親 & 原派 & \\
\hline
\end{tabular}

\begin{tabular}{|l|l|l} 
原在善 & 原派 & \\
\hline 西村桶亭 & 月 $山$ 派 & 綾小路室町西 \\
\hline
\end{tabular}

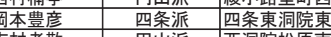

\begin{tabular}{|l|l|l} 
吉村孝文 & 円山派 & 西洞院松原南 \\
\hline 公文 & 四条派 & 堺町四条北 \\
\hline
\end{tabular}

横山華山 芹山派绵小路西洞涫東

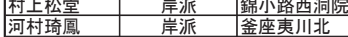

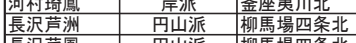

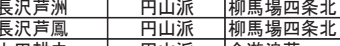

\begin{tabular}{|lll}
\hline 上田耕夫 & 円山派 & 今遊浪華 \\
\hline
\end{tabular}

\begin{tabular}{|l|l|l|}
\hline 迫岡規礼 & 山本家 & 大宮元誓願寺南 \\
\hline 紀広成 & 四条派 & 四条東洞院西
\end{tabular}

\begin{tabular}{lll} 
甲賀文麗 & 望月派 & 白川倒梅宮町 \\
\hline
\end{tabular}

\begin{tabular}{lll} 
土岐済美 & 円山派 & 中長者町新町 \\
\hline
\end{tabular}

\begin{tabular}{ll|l} 
小田海供 & 四条派 & 耐替二条条南 \\
\hline
\end{tabular}

\begin{tabular}{|l|l|}
\hline 田百川 & 両替二条南 \\
\hline 油小路夷川北
\end{tabular}

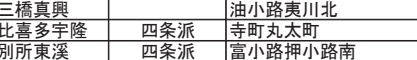

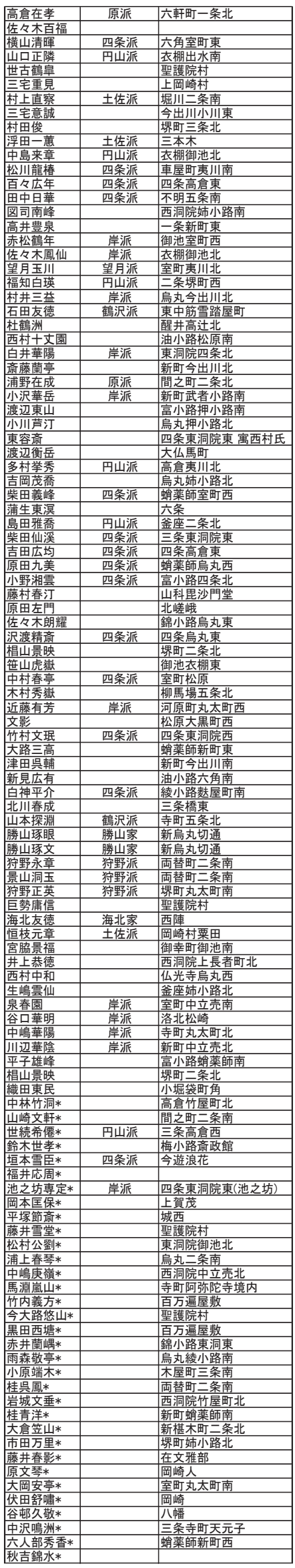




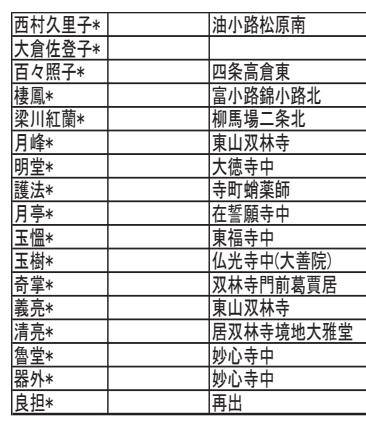

表2-8 『平安人物志『天保年版 (1838)

\begin{tabular}{|c|c|c|c|c|c|}
\hline 名前 & 流派 & 居所 & 䵡田田西塘* & & 鿓万遍屋敖 \\
\hline 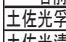 & 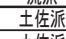 & 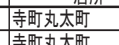 & 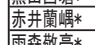 & & 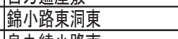 \\
\hline 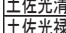 & 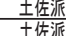 & 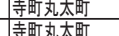 & 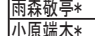 & & 鳥丸綾小路南 \\
\hline 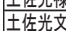 & 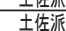 & 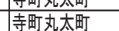 & 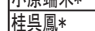 & & 兩替町二条南 \\
\hline 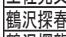 & 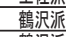 & 下長者町干本東 & 宸城文立垂* & & 西洞院行屋町北 \\
\hline 沢探龍 & 鸛呮派 & 下長者町千本東 & 柱青洋* & & 新町蝴薬師南 \\
\hline 永童 & 狩野派 & 町下立売南 & 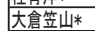 & & 新椹木町二条北 \\
\hline 野永永朝 & 狩野派 & 鳥丸下靖売南 & 㠳田万里* & & 赫町姉小路北 \\
\hline 侖山応震 & 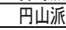 & 牛小路室町東 & 今大路悠山* & & 聖護院 \\
\hline 岸駒 & 岸派 & 北岩倉 & 原文琴* & & 涌崎 \\
\hline & 岸派 & 逨洞院丸太町南 & 优田舒演* & & 岡崎 \\
\hline 岸薜 & 滛派 & 逨洞院丸太町南 & 谷郆人敬* & & 八幡 \\
\hline & 岸派 & & 厕吉錦水* & & \\
\hline & 岸派 & 窒町四条南 & 草藤春英* & 四条派 & 六觡小路西 \\
\hline 岸犍山 & 岸派 & 㮝馬場押小路北 & 歷川|相絲* & & \\
\hline 原在明 & 原派 & 中立売窑町東 & 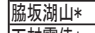 & & 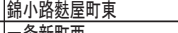 \\
\hline & & 中立売窒町東 & 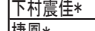 & & 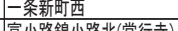 \\
\hline 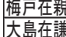 & 原派 & 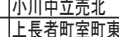 & 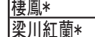 & & 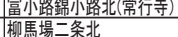 \\
\hline 大口秃䓔 & & 三条洞部東 & 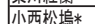 & & 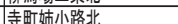 \\
\hline & 円山派 & 高倉夷川北 & 同峰夆 & & 双林寺 \\
\hline 奛雅堷 & 円山派 & 釡座二条北 & 義亳* & & 叒林寺 \\
\hline 重就 & & 武者小路窒町西 & 清亮* & & 双林寺寺在大雅堂 \\
\hline 本豊彦 & 四条派 & 四条東洞院東 & 爑法* & & 寺町略藥師 \\
\hline 村景文 & 四条派 & 四条東洞院西 & 丙槛* & & 東福寺中 \\
\hline 松堂 & 岸派 & 鐔小路西洞院東 & 压槆炏 & & 仏光寺中(大善院) \\
\hline 松巊 & 岸派 & 鍾小路西洞院東 & 奮堂* & & 妙心寺中 \\
\hline & 岸派 & 䋡座库川北 & 器外* & & 妙心寺中 \\
\hline & 四条派 & 四条東洞院西 & 照阿 & & 霊山 \\
\hline 坒沢芦河 & 开山派 & 楖馬場四条北 & 大含* & & \\
\hline & 开山派 & 楖馬場四条北 & 子然* & & 䇾原走寺中 \\
\hline & 望月派 & 白川㨽梅宮町 & 随媯* & & 鋀天神 \\
\hline & 四条派 & 新町四条北 & 㬎明* & & 㜅山山行光坊 \\
\hline & 开山派 & 富小路㭏小路北 & & & 一条智恵光院中 \\
\hline & 四条派 & 堁町町四条北 & 山田竜淵* & 四条派 & 四条富小路東 \\
\hline
\end{tabular}

福知白瓘祭山派 二条堺町西

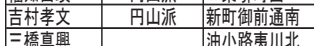

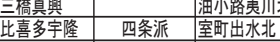

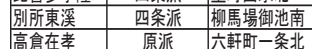

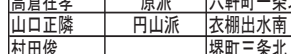

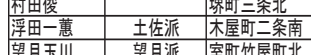

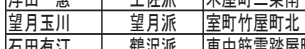

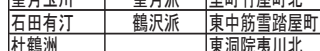

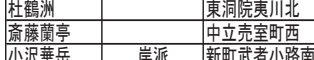

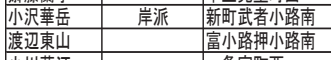

\begin{tabular}{l|l}
\hline 小川芦汀 & - 条室町西 \\
\hline
\end{tabular}

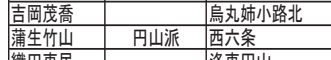

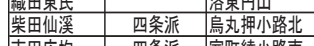

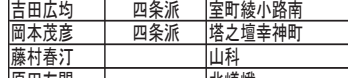

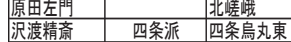

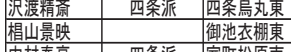

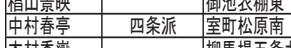

近藤䒴芳

竹村文珢四条派 四条洞院西

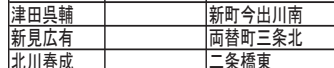

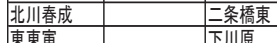

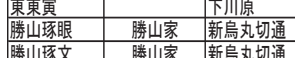

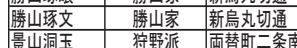

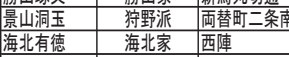

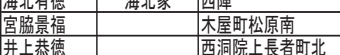

泉春園 岸派 室町中立売南

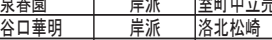

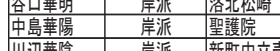

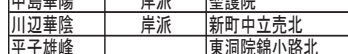

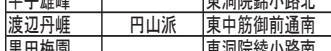

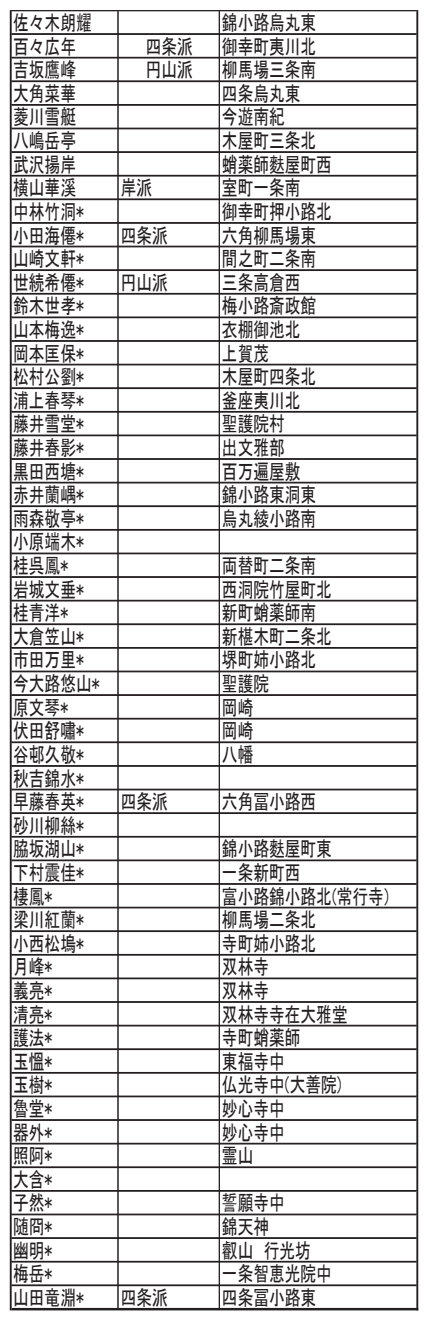

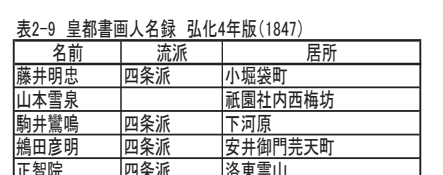

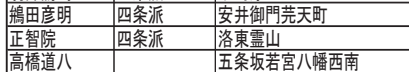

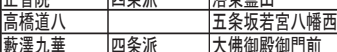

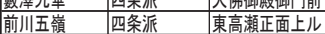

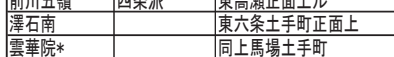

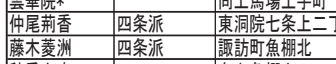

\begin{tabular}{|l|l|l|}
\hline 㷋香女史 & & 烏丸魚棚上 \\
\hline 通口鹤秀 & 岸派 & 不明門通魚棚 \\
\hline
\end{tabular}

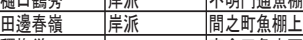

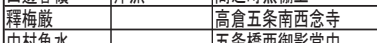

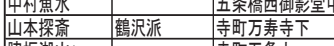

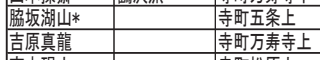

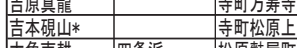

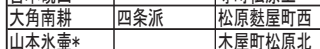

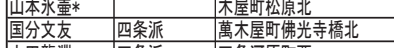

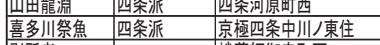

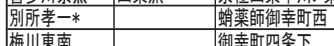

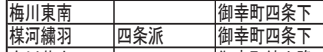

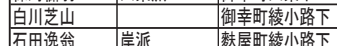

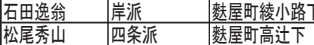

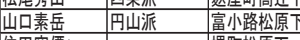

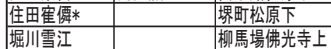

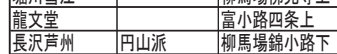

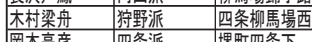

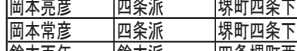

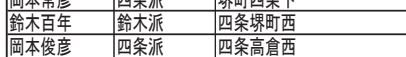

\begin{tabular}{|l|l|l|}
\hline 岡本俊彦 & 四条派 & 四条高倉西西信 \\
\hline 四条派 & 四条東洞院東 \\
\hline
\end{tabular}

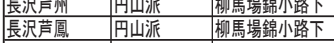

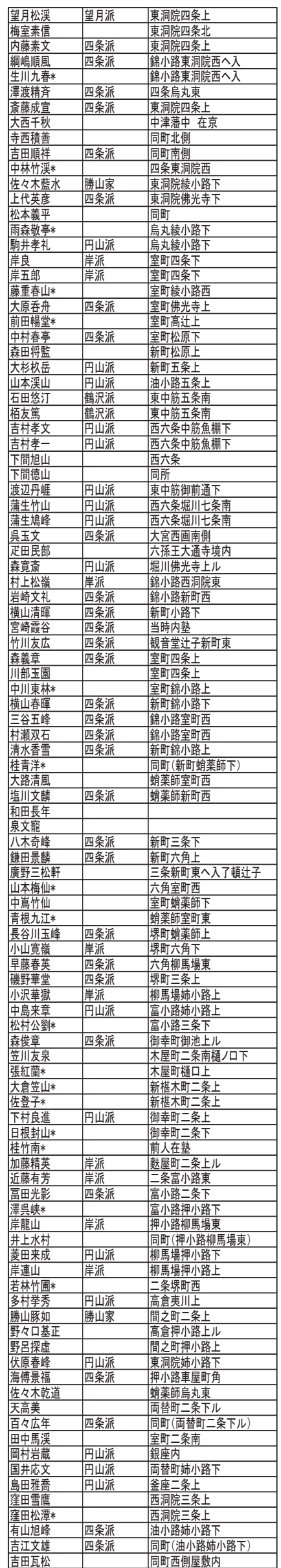




\begin{tabular}{|c|c|c|}
\hline 名前 & 流派 & 居所 \\
\hline 土佐光学 & 土佐派 & \begin{tabular}{|l|l} 
寺町丸太町 \\
\end{tabular} \\
\hline 土佐光清 & 土佐派 & 寺町丸太町 \\
\hline 土佐光文 & 土佐派 & 寺町丸太町 \\
\hline 鶴沢探龍 & 鶴沢派 & 下長者町千本東 \\
\hline 狩野永岳 & 狩野派 & 室町丸太町東 \\
\hline 勝山玩文 & 勝山家 & 新鳥丸切通 \\
\hline 岸岱 & 岸派 & 東洞院丸太町 \\
\hline 岸礼 & 岸派 & 室町四条南 \\
\hline 岸良 & 岸派 & 岩倉 \\
\hline 岸連山 & 岸派 & 柳馬場二条南 \\
\hline 岸誠 & 岸派 & 岸岱三男父同居 \\
\hline 原在照 & 原派 & 中立売室町東 \\
\hline 梅戸在親 & 原派 & 小川中立売北 \\
\hline \multicolumn{3}{|l|}{ 大口秀芳 } \\
\hline 多村挙秀 & 円山派 & 高倉夷川北 \\
\hline 島田雅喬 & 円山派 & 釜座二条北 \\
\hline 座田重就 & & 武者小路室町西 \\
\hline 下村一幸 & 円山派 & 御幸町二条北 \\
\hline 河村琦鳳 & 岸派 & 洛北市原 \\
\hline 椧泉為恭 & & 西洞院下立売北 \\
\hline 横山清暉 & 四条派 & 新町四条北 \\
\hline 中島来章 & 円山派 & 富小路姉小路北 \\
\hline 㸵村孝文 & 円山派 & 崬中筋魚棚南 \\
\hline 長沢芦鳳 & 円山派 & 柳馬場四条南 \\
\hline 同山応立 & 円山派 & 姉小路両替町 \\
\hline 高倉在孝 & 原派 & 六軒町一条北 \\
\hline 望月玉川 & 望月派 & 新町丸太町北 \\
\hline 狩野永朝 & 狩野派 & 室町丸太町南 \\
\hline 高橋正順 & & 菄洞院綾小路南 \\
\hline 宸上松嶺 & 岸派 & 錦小路西洞院東 \\
\hline 小川芦汀 & & 一条室町西 \\
\hline 蒲生竹山 & 円山派 & 西六条 \\
\hline 柴田仙溪 & 四条派 & 東洞院夷川北 \\
\hline 吉田公均 & 四条派 & 堺町二条南 \\
\hline 藤村春汀 & & 山科 \\
\hline 原田左門 & & 北嵯峨 \\
\hline 沢渡精斉 & 四条派 & 四条烏丸東 \\
\hline 中村春亭 & 四条派 & 室町松原南 \\
\hline 木村秀嶽 & & 柳馬場五条北 \\
\hline 岸龍山 & 岸派 & 押小路柳馬場東 \\
\hline 竹村文理 & 四条派 & 堺町三条北 \\
\hline 津田呉輔 & & 新町今出川南 \\
\hline 吉坂鷹峰 & 円山派 & 六角富小路西 \\
\hline 勝山玩如 & 勝山家 & 間之町二条北 \\
\hline 泉春園 & 岸派 & 一条室町十丈坊辻子 \\
\hline 谷口華明 & 岸派 & 室町一条北 \\
\hline 中島華陽 & 岸派 & 聖護院村 \\
\hline 度辺丹崕 & 円山派 & 東中筋御前通南 \\
\hline \multicolumn{3}{|l|}{ 黑田梅園 } \\
\hline 大角菜華 & & 四条烏丸東 \\
\hline 鈴木百年 & 鈴木派 & 四条堺町西 \\
\hline 武沢揚岸 & & 大宮一条南 \\
\hline 横山華溪 & 岸派 & 室町一条南 \\
\hline 岡本亮彦 & 四条派 & 堺町四条南 \\
\hline 岡本常彦 & 四条派 & 東洞院四条北 \\
\hline 吉田順祥 & 四条派 & 四条東洞院西 \\
\hline 山田竜淵 & 四条派 & 四条川原町西 \\
\hline 塩川文鱗 & 四条派 & 蛸薬師新町西 \\
\hline 森俊章 & 四条派 & 御幸町御池北 \\
\hline 大原吞舟 & 四条派 & 室町仏光寺南 \\
\hline \begin{tabular}{|l} 
菻蘭雅 \\
\end{tabular} & 四条派 & 塔之檀桜木丁 \\
\hline 駒并孝礼 & 円山派 & 鳥丸綾小路南 \\
\hline 石田逸翁 & 岸派 & 東洞院蛸薬師南 \\
\hline 吉江文雄 & 四条派 & 小川蛸薬皈扎西 \\
\hline 日根対山 & & 両替町御池南 \\
\hline 森寛斎 & 円山派 & 堀川仏光寺北 \\
\hline
\end{tabular}

\begin{tabular}{|c|c|c|}
\hline 森義章 & 四条派 & 室町四条北 \\
\hline 近沢百峰 & & 御幸町錦小路北 \\
\hline 笠川友泉 & & 富小路二条南 \\
\hline 木村梁舟 & 狩野派 & 崽条柳馬場西 \\
\hline 山本探斎 & 鶴沢派 & 寺町万寿寺南 \\
\hline $\begin{array}{l}\text { 崮边春嶺 } \\
\end{array}$ & & 蕳之町魚棚北 \\
\hline 樋口翠江 & & 不明門通魚棚 \\
\hline 佐々木藍水 & & 東洞院綾小路南 \\
\hline 分木奇峰 & 四条派 & 新町三条南 \\
\hline 岸順堂 & 岸派 & 蚺替町押小路北 \\
\hline 早藤春英 & 四条派 & 六角麩屋町角 \\
\hline 石田悠汀 & 鶴沢派 & 東中筋五条南 \\
\hline 海北友樵 & 海北家 & 塔之檀 \\
\hline 上田桃嶺 & 四条派 & 伏見両替町 \\
\hline 中川雲屏 & & 仏光寺柳馬場西 \\
\hline 栢友麻 & 鶴沢派 & 東中筋五条南 \\
\hline 三谷五峰 & 四条派 & 錦小路室町西 \\
\hline 高松圭隣 & & 間之町二条南 \\
\hline 織田梅坡 & & 広小路寺町東 \\
\hline 仲尾荆香 & 四条派 & 東洞院七条南 \\
\hline 松村月樵 & 四条派 & 四条麩屋町東 \\
\hline 林耕雲 & 四条派 & 十丈坊辻子 \\
\hline 辰谷川玉峰 & 四条派 & 柳馬場三条北 \\
\hline 窪田雪鷹 & & 釡座夷川北 \\
\hline 山口素岳 & 円山派 & 輻小路松原南 \\
\hline 有山他峰 & 四条派 & 油小路御池南 \\
\hline 箕田霞峰 & & 御室 \\
\hline 藤木菱洲 & & 諁訪町五条南二町 \\
\hline 岡村雪峰 & & 両替町押小路南 \\
\hline 小野玉嶺 & 望月派 & 衣棚押小路北 \\
\hline 国分文友 & 西条派 & 松原愛宕寺中 \\
\hline 中川江雲 & & 新椹木町丸太町南 \\
\hline 村瀬雙石 & 四条派 & 錦小路室町西 \\
\hline 山口連谷 & & 堺町夷川北 \\
\hline 宮崎周輔 & & 新町四条北 \\
\hline 泉梅泉 & & 蛸薬師新町西 \\
\hline 菱田来成 & & 柳馬場押小路南 \\
\hline 会高美 & & 鳥丸丸太町南 \\
\hline 林其山 & & 黒門中立売南 \\
\hline 馬帰梱山 & & 鞍馬口室町 \\
\hline 礒田塵山 & & 柳馬場四条南 \\
\hline 中林竹洞* & & 真如堂前 \\
\hline 小田海供* & 四条派 & 六角柳馬場東 \\
\hline 山本梅晩* & & 富小路六角南 \\
\hline 岡本匡保* & & 上賀茂 \\
\hline \multicolumn{3}{|l|}{ 藤井春影* } \\
\hline 黑田西塘* & & 百万遍屋敷 \\
\hline \multicolumn{3}{|l|}{ 雨森敬亭* } \\
\hline 桂㝵鳳** & & 両替町二条南 \\
\hline 嵀青洋* & & 新町蛸薬師南 \\
\hline 原文琴* & & 岡崎 \\
\hline 伏田舒啸* & & 為崎 \\
\hline \multicolumn{3}{|l|}{ 秋吉錦水* } \\
\hline 義兑* & & 双林寺 \\
\hline 清亮* & & 双林寺寺大雅堂 \\
\hline \multicolumn{3}{|l|}{ 砂川柳絲* } \\
\hline 中林竹溪* & & 四条烏丸東 \\
\hline 脇坂湖山* & & 寺町姉小路北 \\
\hline 住田鶴仙* & & 高辻高倉西 \\
\hline 後藤田南溪* & & 岡崎 \\
\hline 青根久江* & & 蛸薬師室町東 \\
\hline 前田暢堂* & & 室町高过北 \\
\hline 生川九春* & & 両替町二条南 \\
\hline 吉本硯山* & & 東洞院四条北 \\
\hline 藤重春山* & & 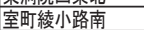 \\
\hline 名草魀峰** & & 富小路蛸薬師南 \\
\hline 沢與峡* & & 富小路御池北 \\
\hline 雁田松潭* & & 富小路御池南 \\
\hline
\end{tabular}

表 1 は『平安人物志』、『皇都書画人名録』、『京羽二重』、『京羽津 根 (京洛羽津根)』における絵師の収録数をまとめたものである。『平 安人物志』は、明和 5 年版（1768）から天明 2 年版（1782）では一 巻一冊だったが、文化 10 年版（1813）から慶応 3 年版（1867）まで は、一冊を上巻・中巻・下巻・付録に分け、『平安人物志』そのもの の収録数が大幅に増加した。また、絵師に限れば、天明の大火後に 行われた寛政度内裏造営において、これまでは御用絵師注 11) のみが 内裏に従事していたが、幕府の財政難から町絵師も従事した注12) こ とで、町絵師の需要が増加したことも背景にあるのではないかと推 測される。『皇都書画人名録』は三条の東から京都を時計回りに回り ながらそれぞれの場所に居所を構える絵師が収録されており、御用 絵師と町絵師を分けた収録はされていない。また、収録数が 246 人 と同時期に発行された『平安人物志』嘉永 5 年版（1852）と比較し ても約 100 人も多く収録されている。『京羽二重』は御用絵師が収録 されている。『京羽二重』貞享 2 年版（1685）の収録数が 5 人である
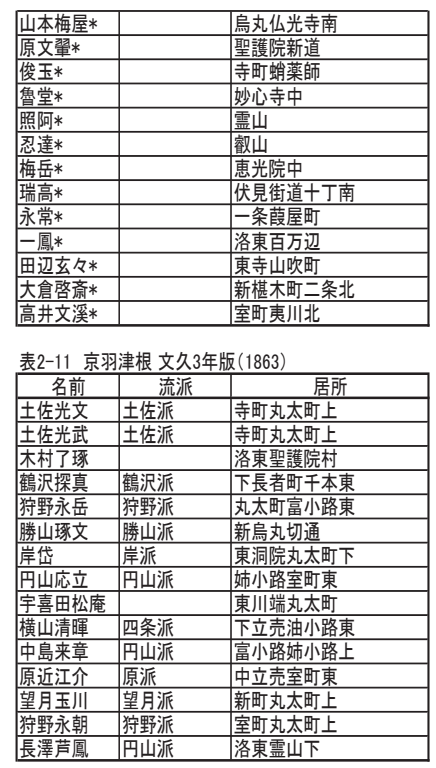

\begin{tabular}{|c|c|c|}
\hline 名前 & 流派 & 居所 \\
\hline 土佐光文 & 土佐派 & 寺町丸太町 \\
\hline 土佐光章 & 土佐派 & 父光文と同居か \\
\hline 土佐光武 & 土佐派 & 光文宅の南隣 \\
\hline 鶴沢探龍 & 鶴沢派 & 下長者町千本東 \\
\hline 岸礼 & 岸派 & 伏見 \\
\hline 岸誠 & 岸派 & 東洞院丸太町南 \\
\hline 岸慎 & 岸派 & 父岸礼と同居か \\
\hline 原在照 & 原派 & 中立売室町東 \\
\hline 梅戸在親 & 原派 & 小川中立売北 \\
\hline 多村挙秀 & 円山派 & 高倉夷川北 \\
\hline 下村良進 & 丹山派 & 東木屋町二条南 \\
\hline 島田雅喬 & 円山派 & 釡座二條北 \\
\hline 中島来章 & 円山派 & 柳馬場御池南 \\
\hline 吉村孝一 & 开山派 & 西六条 \\
\hline 長沢芦鳳 & 开山派 & 八坂枡屋町 \\
\hline 円山応立 & 円山派 & 姉小路両替町 \\
\hline 高倉在孝 & 原派 & 六軒町一条北 \\
\hline 小川芦汀 & & -条室町西 \\
\hline 蒲生竹山 & 円山派 & 西六条 \\
\hline 柴田仙渓 & 四条派 & 菄洞院夷川北 \\
\hline 藤村春汀 & & 山科 \\
\hline 原田左門 & & 北峻峨 \\
\hline 沢渡精斎 & 四条派 & 四条烏丸東 \\
\hline 沢渡素軒 & 四条派 & 父精斎と同居 \\
\hline 中村春亭 & 四条派 & 室町松原南 \\
\hline 不村秀嶽 & & 柳馬場五条北 \\
\hline 竹村文珢 & 四条派 & 堺町三条北 \\
\hline 䢖田遂輔 & & 新町今出川南 \\
\hline 唐坂鷹峰 & 円山派 & \\
\hline 中島有章 & 円山派 & 父来章と同居 \\
\hline 勝山柇如 & 勝山家 & 間之町二条北 \\
\hline 泉春園 & 岸派 & 一条室町十又坊辻子 \\
\hline 谷口華明 & 岸派 & 室町一条北 \\
\hline 中島華陽 & 岸派 & 聖護院村 \\
\hline
\end{tabular}

\begin{tabular}{|c|c|c|}
\hline 武沢揚岸 & & 大宮－条南 \\
\hline 岡本亮彦 & 四条派 & 堺町四条北 \\
\hline 岡本常彦 & 四条派 & 木屋町四条南 \\
\hline 鈴木百年 & 鈴木派 & 四条高倉西 \\
\hline 塩川文鱗 & 四条派 & 木屋町四条三丁南 \\
\hline \begin{tabular}{|l|} 
菻蘭雅 \\
\end{tabular} & 四条派 & 塔之段 \\
\hline 森義章 & 四条派 & 两替町三条北 \\
\hline 木村梁舟 & 狩野派 & 四条柳馬場西 \\
\hline 田辺春嶺 & & 間之町魚棚北 \\
\hline 樋口翠江 & & 東六条 \\
\hline 佐々木藍水 & & 洛東八坂 \\
\hline 八木奇峰 & 四条派 & 衣棚御池南 \\
\hline 海北友樵 & 海北家 & 塔之段 \\
\hline 中川雲屏 & & 仏光寺柳馬場西 \\
\hline 早藤春英 & 四条派 & 川端四条北 \\
\hline 栢友鷹 & 鶴沢派 & 東中筋五条南 \\
\hline 林耕雲 & 四条派 & 十文字辻子 \\
\hline 辰谷川玉峰 & 四条派 & 柳馬場三条北 \\
\hline 有山旭峰 & 四条派 & 油小路御池南 \\
\hline 藤木菱洲 & & 諏訪町五条南二丁 \\
\hline 岡村雪峰 & & 両替町押小路南 \\
\hline 小野王嶺 & 望月派 & 衣棚押小路北 \\
\hline 国分文友 & 四条派 & 松原愛宕寺中 \\
\hline 中川江雲 & & 新椹木町丸太町 \\
\hline 麻瀬双石 & 四条派 & 上京 \\
\hline 天高美 & & 鳥丸丸太町南 \\
\hline 林其山 & & 黑門中立売南 \\
\hline 馬淪旭山 & & 鞍馬口室町 \\
\hline 青龍山 & & 岡崎 \\
\hline 川端玉章 & 円山派 & 四条東洞院西 \\
\hline 小島彫斎 & & 堺町六角南 \\
\hline 高橋正順 & & 東洞院綾小路南 \\
\hline 大角有隣 & & 洛東吉田 \\
\hline 岸竹堂 & 岸派 & 柳馬場押小路北 \\
\hline 蒲生鳩峰 & & 西六条 \\
\hline 渡辺丹崕 & 円山派 & \\
\hline 西山元鳳 & & 新門前縄手東 \\
\hline 岡嶋清嚝 & 四条派 & 富小路姉小路北 \\
\hline 熊谷直彦 & 四条派 & 高倉三条角 \\
\hline 前川五嶺 & 四条派 & 堺町松原下 \\
\hline 前川文嶺 & 四条派 & 父五嶺宅に同居 \\
\hline 竹川友広 & 円山派 & \\
\hline 通口翠岳 & & 父翠江の東六条に同居 \\
\hline 岡本匡保* & & 賀茂 \\
\hline 黑田西塘* & & 百万遍屋敷 \\
\hline 清亮* & & 双林寺大雅堂 \\
\hline \multicolumn{3}{|l|}{ 砂川柳絲* } \\
\hline 中林竹溪* & & 岡崎 \\
\hline 桂吳鳳* & & 両替町二條南 \\
\hline 前田暢堂* & & 木屋町松原北 \\
\hline 日根対山* & & 聖護院村 \\
\hline 名草逸峰* & & 衣棚御池北 \\
\hline 山本梅屋* & & 鳥丸仏光寺南 \\
\hline 永常* & & 一条澱屋町 \\
\hline -鳳* & & 面万遍 \\
\hline 真亮* & & 洛東双林寺 \\
\hline 原文墰* & & 御幸町二条南 \\
\hline \multicolumn{3}{|l|}{ 大倉啓斎* } \\
\hline 高井文溪* & & 高辻柳馬場西 \\
\hline 山口碧海* & & 御幸町二條角 \\
\hline 重春塘* & & 柳馬場二條北 \\
\hline 上野雪岳* & & 鳥丸仏光寺南 \\
\hline 森香邨* & & 大宮七条北 \\
\hline 中西耕石* & 四条派 & 清水三丁目 \\
\hline 中西耕䊖* & & 木屋町三条北 \\
\hline 中西松石* & 四条派 & 醒井奥棚南 \\
\hline \multicolumn{3}{|l|}{ 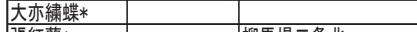 } \\
\hline 張紅蘭* & & 柳馬場二条北 \\
\hline
\end{tabular}

こと、さらに『平安人物志』明和 5 年版（1768）との時代差が約 80 年であることを考慮し、本稿において、『京羽二重』は考察対象外と した。『京羽津根 (京洛羽津根)』は町絵師も収録されるが、御用絵 師が先に収録され、御用絵師と町絵師を分けて収録している。表 2 は『平安人物志』、『皇都書画人名録』、『京羽二重』、『京羽津根（京 洛羽津根)』に収録される絵師の一覧である注 13 )。

\section{3. 年代別における居住分布}

\section{3-1. 明和から天明における居住分布}

『平安人物志』明和 5 年版 (1768)、『平安人物志』安永 4 年版 (1775) によると、居住分布は全体に分散しており、その傾向は看取できな い（図 1、図 2)。『平安人物志』天明 2 年版（1782）によると、四条 堺町から四条高倉には $10.3 \%$ 注 14$)$ 、二条東洞院から二条新町には 13. $8 \%$ の割合で絵師が居所を構えており、特定の通りに居所を構え る傾向が天明から確認できる（図 3)。 


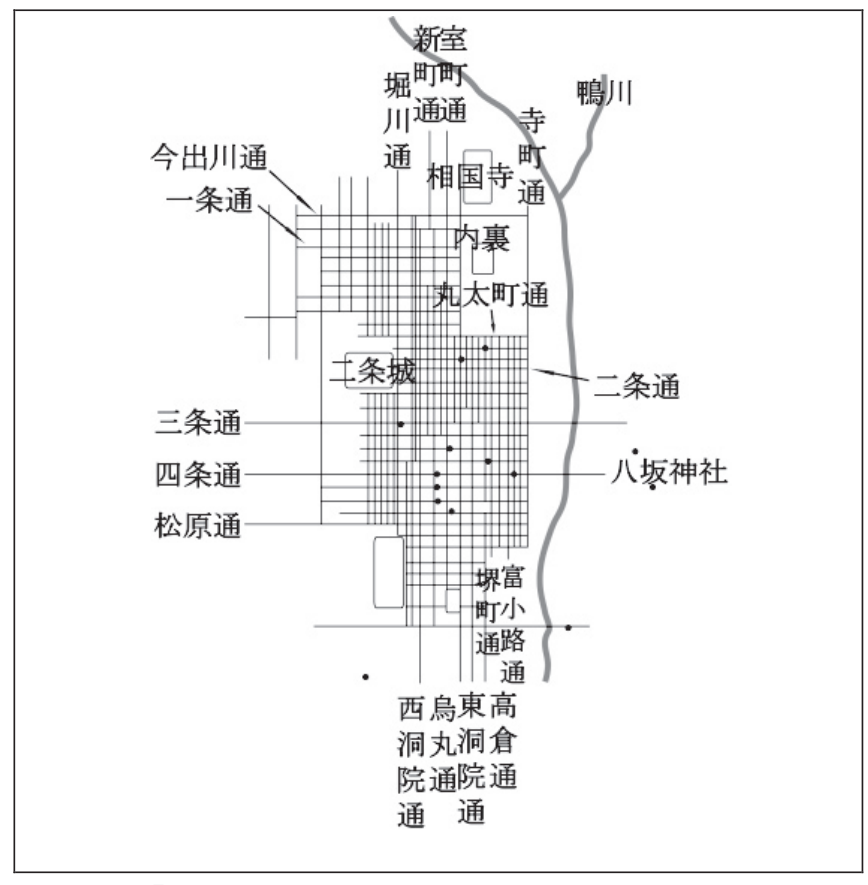

図 1 『平安人物志』明和 5 年版（1768）にみえる居住分布

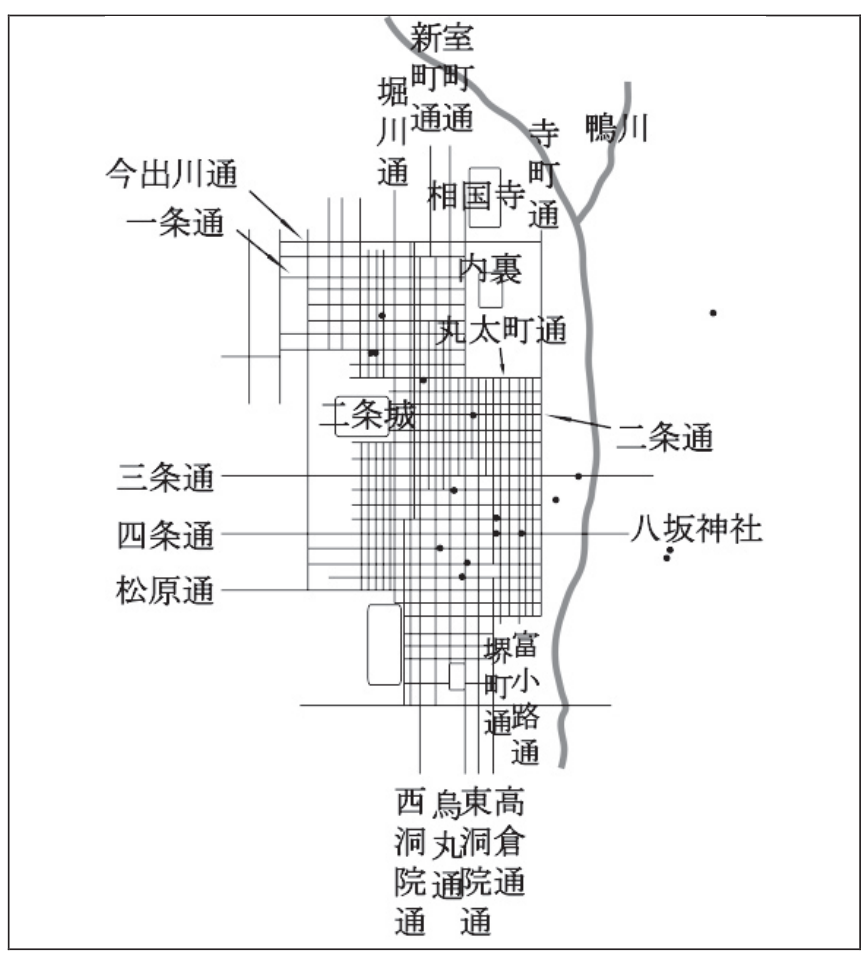

図 2 『平安人物志』安永 4 年版（1775）にみえる居住分布

\section{3-2. 文化から天保における居住分布}

『平安人物志』文化 10 年版（1813）によると、四条富小路から四 条室町には $11.8 \%$ 、三条富小路から三条烏丸には 5.4\%の割合で絵 師が居所を構える。また、内裏周辺に居所を構える絵師が登場する が、詳細は 4 章で述べる (図 4)。『平安人物志』文政 5 年版 (1822) によると、二条通には $9.4 \%$ 、四条通には $8.5 \%$ の割合で絵師が居所 を構える。特に二条両替町における居住分布が集中し、特定の地域 に居所を構える傾向が文政から確認できる。また、内裏西方に居所 を構える絵師が増加することも注目すべき傾向である（図 5)。『平

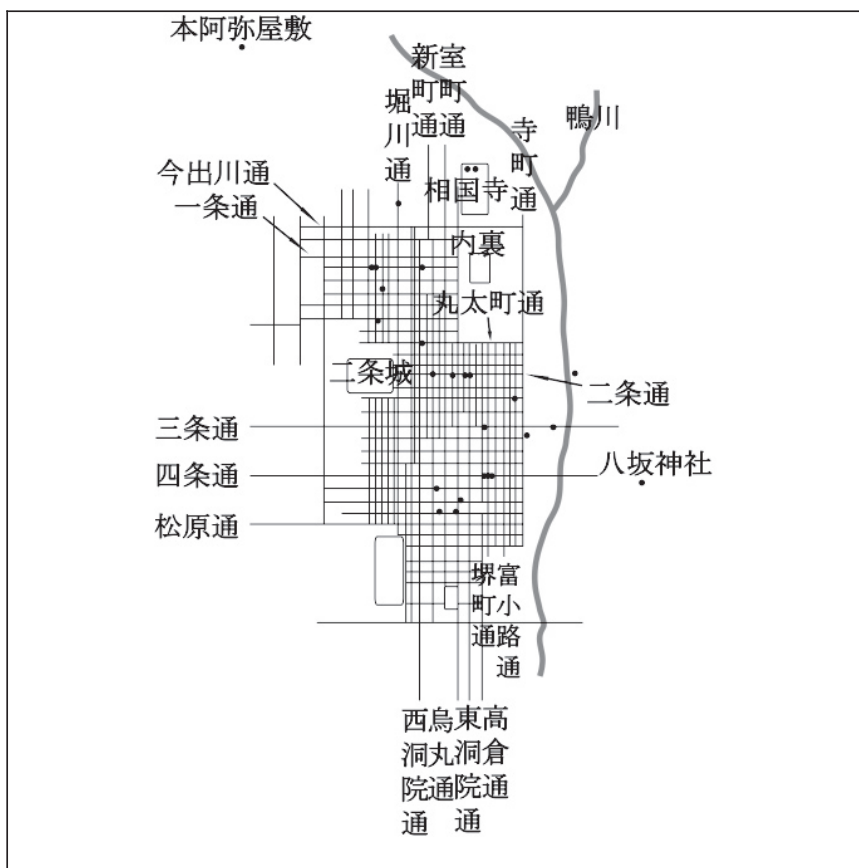

図 3 『平安人物志』天明 2 年版（1782）にみえる居住分布

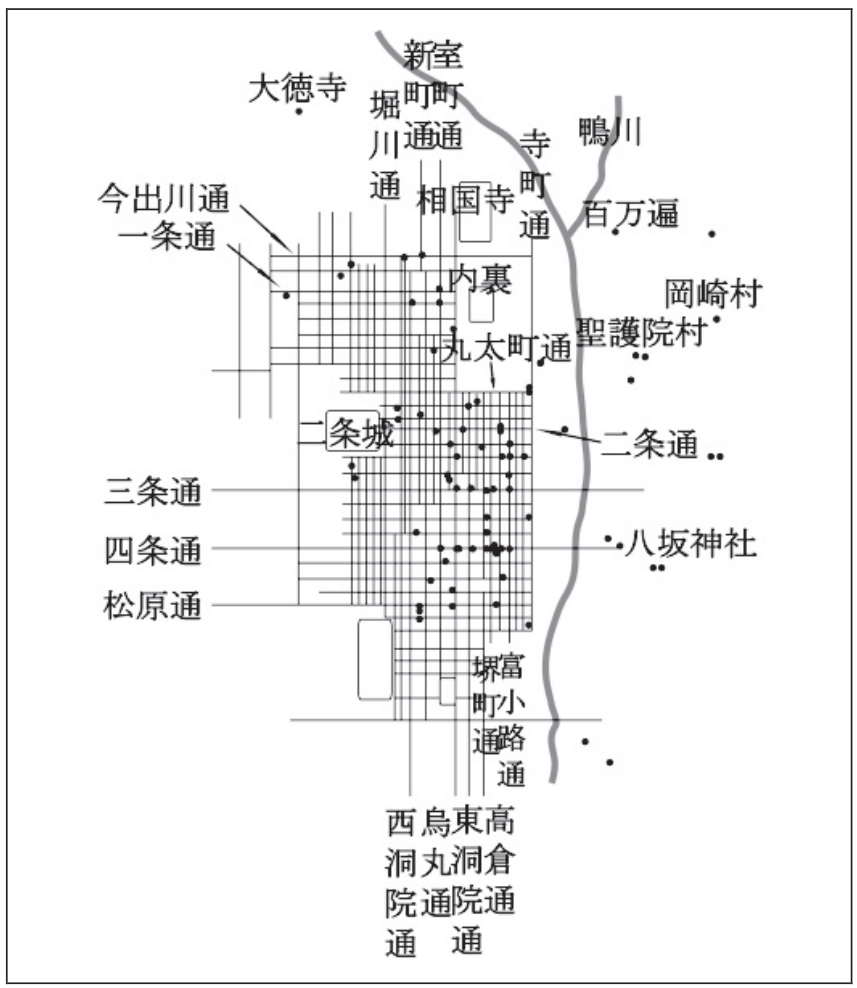

図 4 『平安人物志』文化 10 年版（1813）にみえる居住分布

安人物志』文政 13 年版（1830）によると、四条通と二条通にはそれ ぞれ $9.2 \%$ 、丸太町通と蛸薬師通にはそれぞれ $4.3 \%$ 割合で絵師が 居所を構える。特定の地域に居所を構える傾向は、二条両替町の他、 寺町丸太町、御池衣棚、四条東洞院において確認できる (図 6)。『平 安人物志』天保 9 年版（1838）によると、四条通には 9.5\%、二条 通には $6.6 \%$ 、錦小路通には $5.8 \%$ 、中立売通には $5.1 \%$ の割合で絵 師が居所を構える。ここでも寺町丸太町、四条東洞院における居住 分布が集中し、新たに室町中立売に集中寸る（図 7)。 


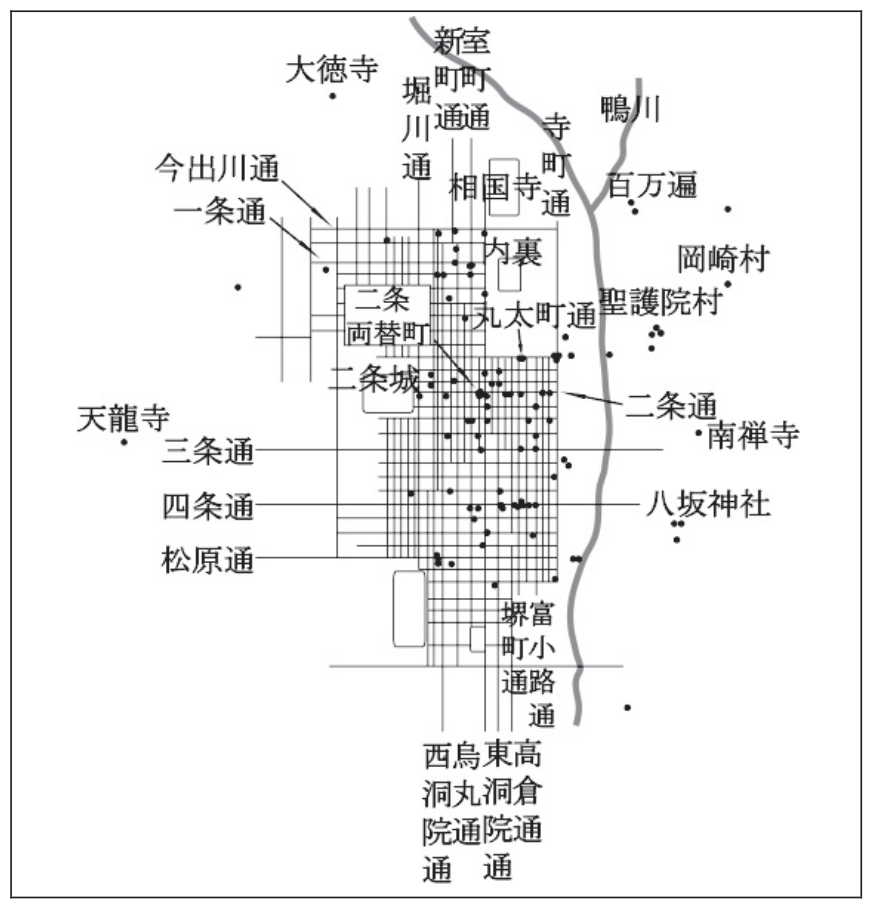

図 5 『平安人物志』文政 5 年版（1822）にみえる居住分布

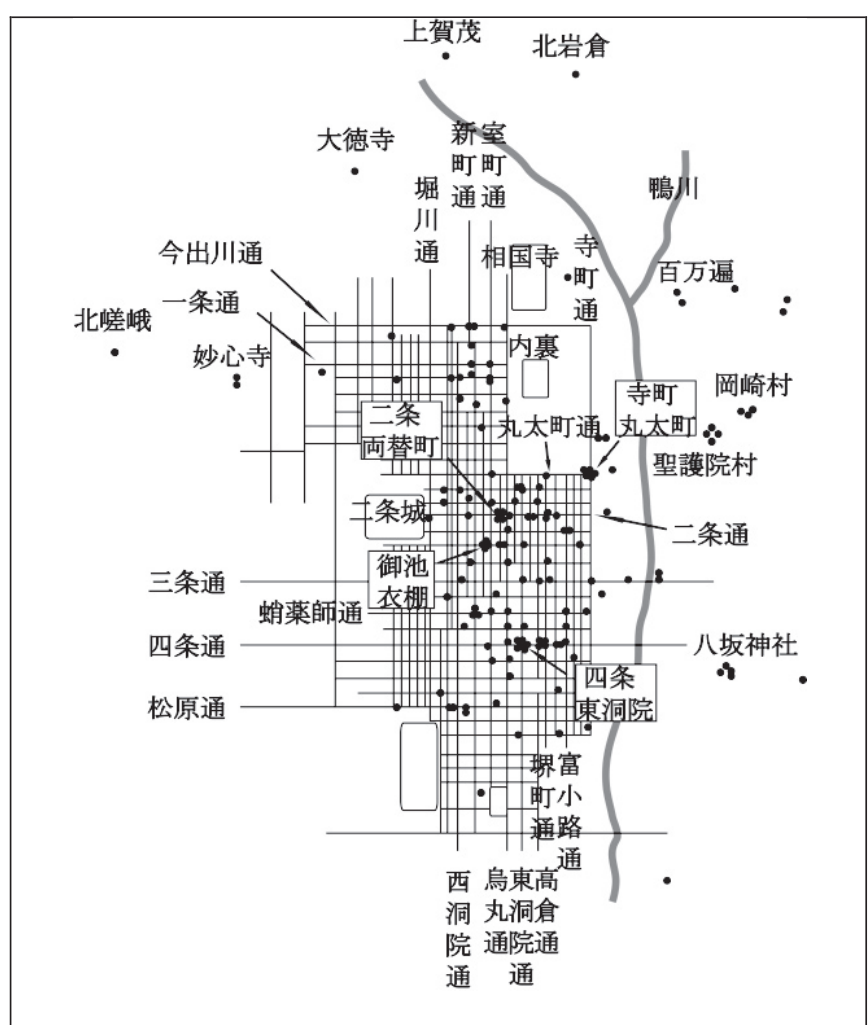

図 6 『平安人物志』文政 13 年版（1830）にみえる居住分布

\section{3-3. 弘化から慶応における居住分布}

『皇都書画人名録』弘化 4 年版（1847）によると、四条通には $8.5 \%$ 、 二条通には $7.3 \%$ 、丸太町通には $5.7 \%$ 、六角室町から松原室町には 6. $1 \%$ の割合で絵師が居所を構える。また、寺町丸太町と四条東洞院 における集中に加え、寺町今出川と東洞院丸太町においても集中す る。四条通以南に居所を構える絵師に注目寸ると、以前より増加す ることが確認できる（図 8)。『平安人物志』嘉永 5 年版（1852）に

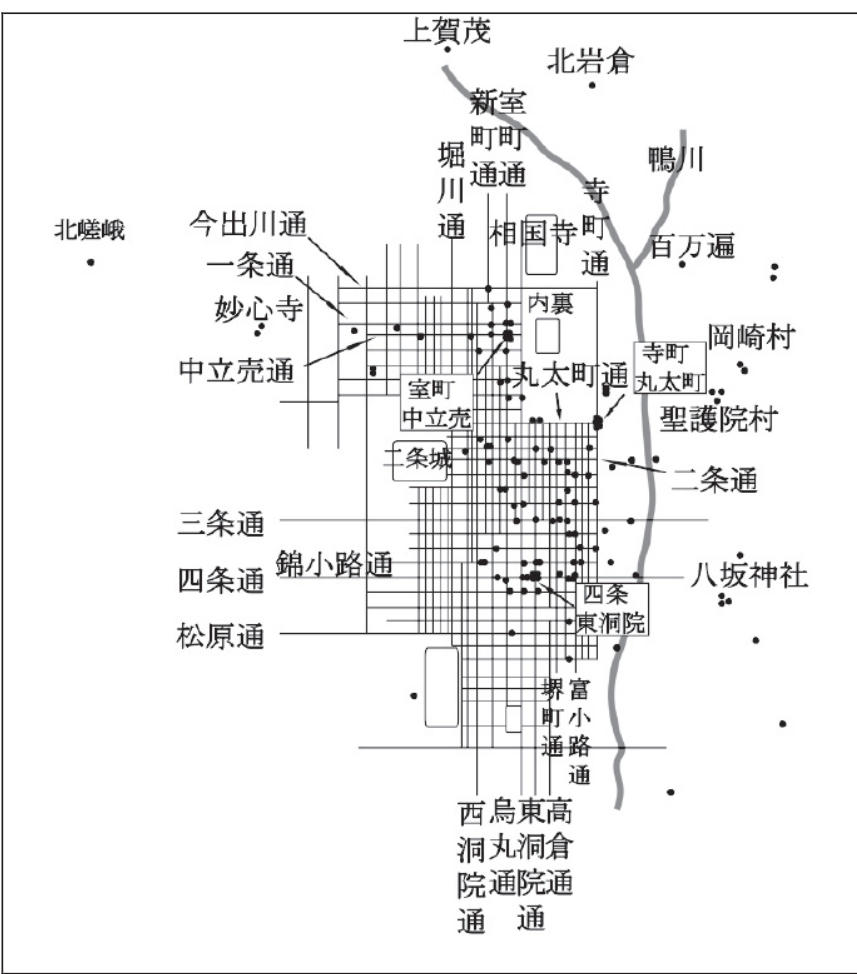

図 7 『平安人物志』天保 9 年版（1838）にみえる居住分布

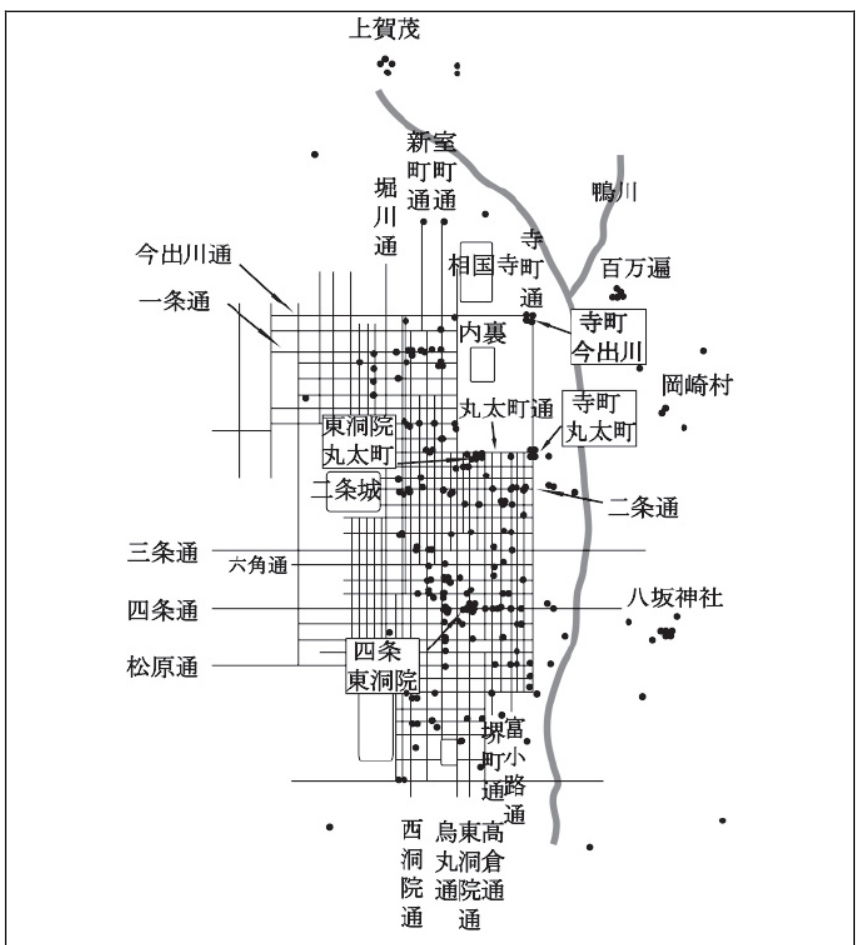

図 8 『皇都書画人名録』弘化 4 年版（1847）にみえる居住分布

よると、室町通には $12.2 \%$ 、四条通には $11.6 \%$ 、二条通と丸太町通 にはそれぞれ $6.8 \%$ の割合で絵師が居所を構える (図 9)。『京羽津根 (京洛羽津根)』文久 3 年版（1863）によると、丸太町通には $46.7 \%$ の割合で絵師が居所を構える (図 10)。『平安人物志』慶応 3 年版 (1867) によると、四条通には $8.8 \%$ 、二条通には 7.8\%、三条通と丸太町通 にはそれぞれ $5.9 \%$ の割合で絵師が居所を構え、さらに、鴨川周辺 においても集中する（図 11）。 


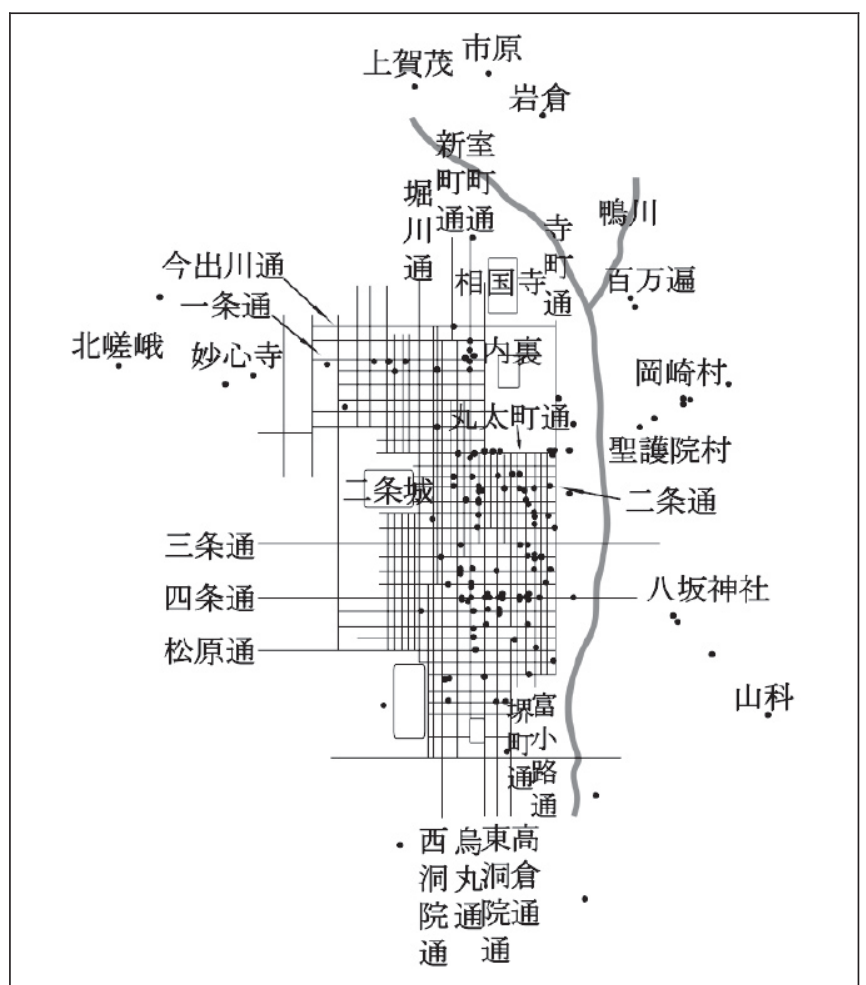

図 9 『平安人物志』嘉永 5 年版（1852）にみえる居住分布

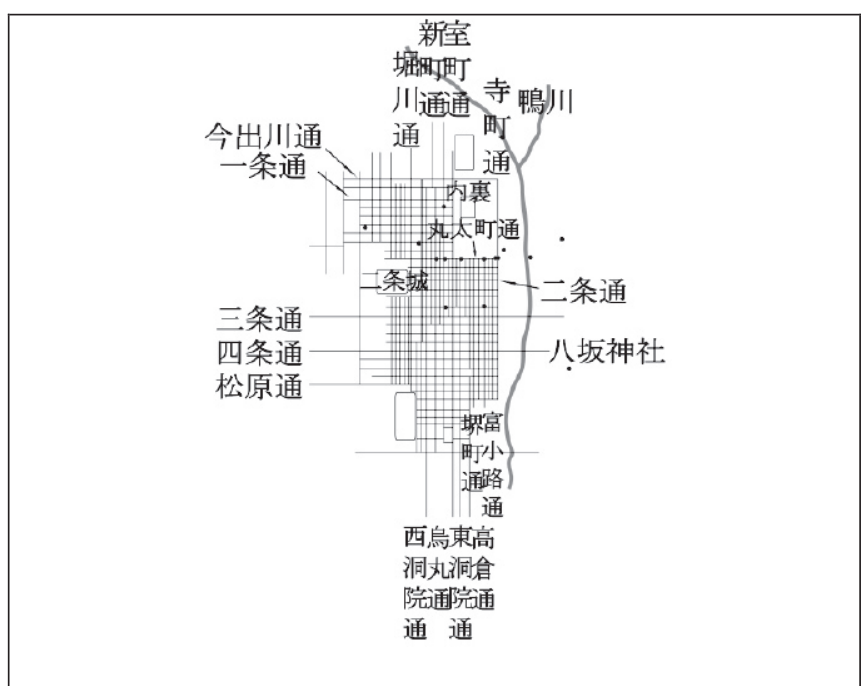

図 10 『京羽津根』文久 3 年版（1863）にみえる居住分布

\section{4. 内裏周辺における居住分布}

『平安人物志』、『皇都書画人名録』、『京羽津根 (京洛羽津根)』に おいて、絵師が内裏周辺に居所を構え始めるのは、『平安人物志』文 化 10 年版 (1813) 以降である。御用絵師は『平安人物志』において、 文化 10 年版 (1813) から登場するが、それ以前から内裏周辺に居所 を構えていた可能性がある。一方、町絵師が内裏周辺に居所を構え るようになったのは、『平安人物志』によると、文化 10 年版 (1813) からである。その背景には、収録数が 29 人（天明 2 年版）から 93 人（文化 10 年版）と増加したことも考えられるが、寛政度内裏造営 への参加が主な要因であると推測される。

四条派は、四条通を中心に居所を構えていたことにその名前の由 来がある。収録数が 137 人（『平安人物志』天保 9 年版）から 246

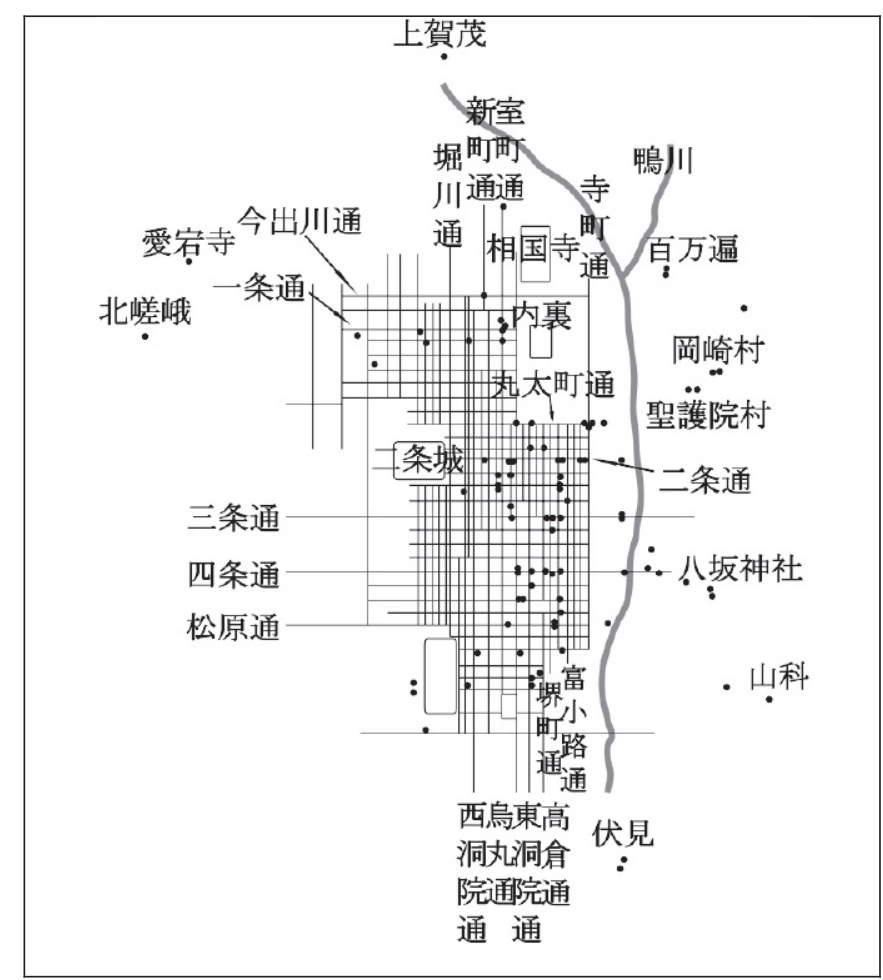

図 11 『平安人物志』慶応 3 年版（1867）にみえる居住分布

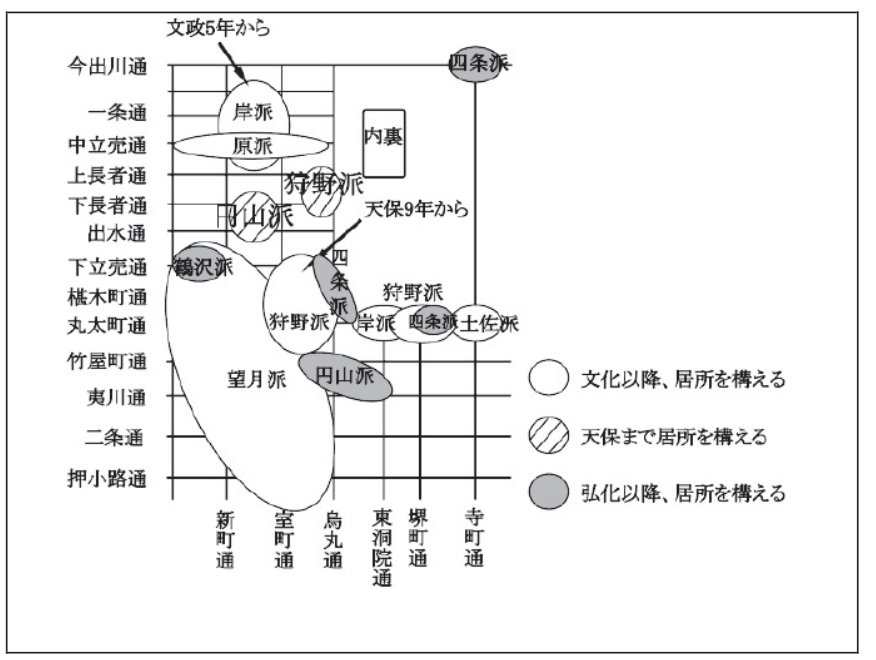

図 12 内裏周辺にみえる絵師の居住分布

人 (『皇都書画人名録』弘化 4 年版) と増加するが、『皇都書画人名 録』弘化 4 年版（1847）において、内裹北東角にあたる寺町今出川 と内裏南方界隈に居所を構え、今出川通にまで居住分布が広がるこ とが分かる。円山派は、『平安人物志』文化 10 年版 (1813) から『平 安人物志』天保 9 年版（1838）によると、内裏西方にあたる下長者 通と出水通に居所を構える。『皇都書画人名録』弘化 4 年版（1847） によると、内裏西方から南方へ移動する。岸派は、『平安人物志』文 化 10 年版（1813）によると、内裏南方にあたる丸太町東洞院界隈に 居所を構える。『平安人物志』文政 5 年版 (1822) から『平安人物志』 慶応 3 年版（1867）によると、丸太町東洞院の他、内裏北西にあた る一条通と中立売通界隈にも居所を構える。内裏北西にあたる中立 売通界郎には、『平安人物志』文化 10 年版（1813）によると、原派 も居所を構える。望月派は、『平安人物志』文化 10 年版（1813）か 
ら『平安人物志』嘉永 5 年版（1852）によると、居所の転移がみら れるが、内裏南西に居所を構える。狩野派注 15$)$ は、『平安人物志』 文化 10 年版（1813）から『平安人物志』文政 13 年版（1830）によ ると、内裏西方と南方に居所を構えるが、『平安人物志』天保 9 年版 （1838）と『平安人物志』嘉永 5 年版（1852）によると、内裏南西 一移動する。土佐派は、『平安人物志』文化 10 年版 (1813) から『平 安人物志』慶応 3 年版（1867）によると、一貫して内裏東南角にあ たる寺町丸太町に居所を構える。鶴沢派は、『皇都書画人名録』弘化 4 年版 (1847) によると内裏西方にあたる下立売通に居所を構える。

文化から天保において、絵師たちは内裏南方と西方に居所を構え ていたが、弘化以降、内裏西方に居所を構える絵師が減少し、内裏 南方に居所を構える絵師が増加する（図 12）。

\section{5. 郊外における居住分布}

表 3 は、表 2 から郊外に居所を構える絵師の一覧を示したもので ある。絵師が郊外に居所を構えるのは、『平安人物志』明和 5 年版 (1768) からみられる。特に祇園界隈は池大雅や池玉欄が居所を構え たのをはじめ、多くの絵師が居所を構えることになる。次いで聖護 院村、百万遍、岡崎村、伏見といった地域が多く、これらはいずれ も『平安人物志』文化 10 年版（1813）からである。その他、北方で は大徳寺、上賀茂、岩倉、西方では妙心寺、北嵯峨、天龍寺、愛宕 寺などが、こちらも文化以降みられる。郊外における居住分布の傾 向は、文人画家が目立ち、その他、四条派、岸派といった町絵師が よくみられる。一方、御用絵師では鶴沢派の竹内重方と土佐派の恒 枝元章のみであり、御用絵師が郊外に居所を構えることは稀である。

このように郊外における居住分布は、文人画家、町絵師らが祇園 界隈、聖護院村、百万遍、岡崎村、伏見、上賀茂、岩倉などの鴨川 以東を中心として文化以降、増加傾向にあることが分かる (図 13)。

\section{6. まとめ}

以上、絵師の居住分布について、その傾向を年代順に看取した。 さらに、これらを通して内裏周辺と郊外における居住分布の傾向も 看取した。本稿は次のようにまとめることができる。

1) 特定の通りに居所を構える傾向が、天明から確認でき、文化以降 その傾向が強くなる。主な通りは、二条通・四条通・三条通・丸 太町通である。

2) 特定の地域に居所を構える傾向が、文政から確認できる。主な地 域は、二条両替町・寺町丸太町・四条東洞院である。

3)弘化以降、四条通以南に居所を構える絵師が増加する。

4) 内裏周辺では、文化から天保において、絵師は内裏南方と西方に それぞれ居所を構えていたが、弘化以降、内裏西方に居所を構える 絵師が減少し、内裏南方に居所を構える絵師が増加する。

5) 郊外に居所を構える絵師は、明和から確認でき、文化以降増加傾 向にある。主な地域は祇園界隈、聖護院村、百万遍、岡崎村、伏 見であり、これらはいずれも鴨川以東である。また、郊外に居所 を構える絵師は、文人画家に多くみられ、町絵師では四条派、岸 派の絵師が多く、御用絵師はあまりみられなかった。

1)については、『平安人物志』の収録数も考慮すべきではあるが、 『平安人物志』天明 2 年版 (1782) から確認できることを考えると、 文化以降の収録数増加がその傾向に拍車を掛けたと考えられる。四
表 3 郊外に居所を構える絵師一覧
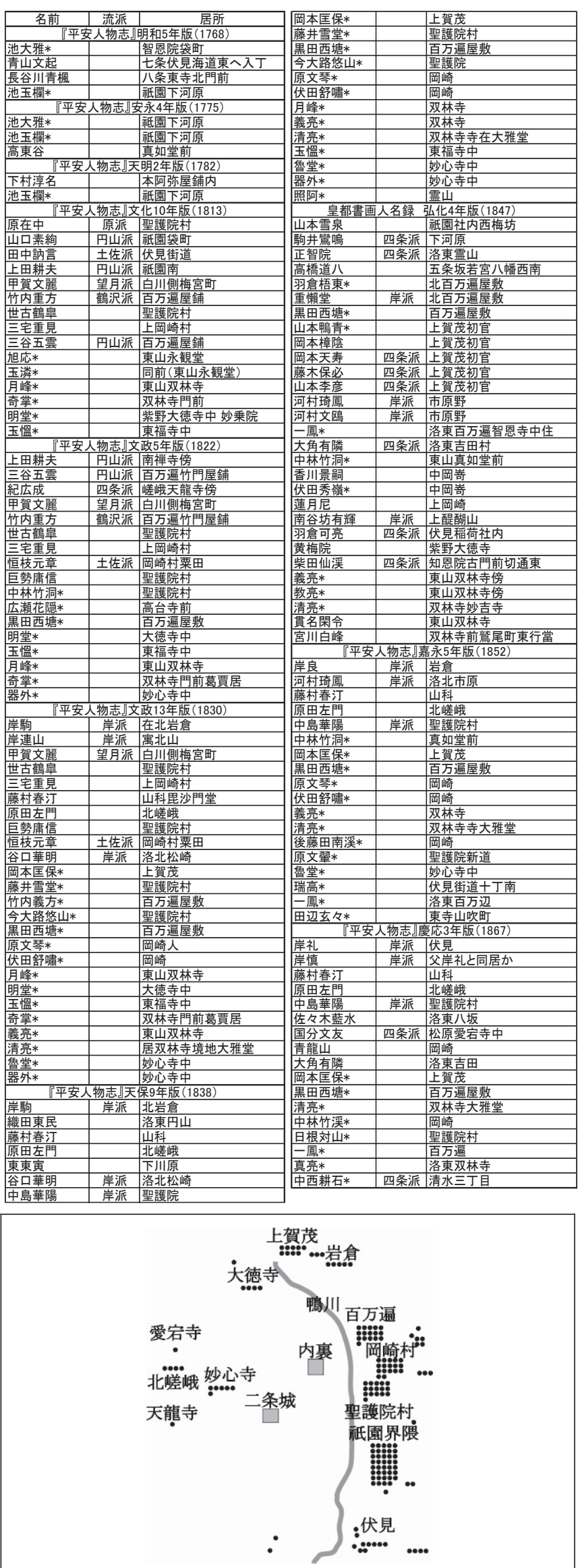

図 13 郊外にみえる絵師の居住分布 
条通における集中は、四条派の存在が大きく関与するものと考えら れるが、文化までは円山派の存在も軽視することはできない。また、 四条通、室町通への集中は並木氏が指摘しているが、四条通は天明 から、室町通は弘化から集中することが本稿で明らかになった。

2)については、『平安人物志』文政 5 年版（1822）から『皇都書画 人名録』弘化 4 年版（1847）にかけて確認できる。御池衣棚と寺町 丸太町を除き、集中寸る通りの範囲内である。寺町丸太町には土佐 派が、四条東洞院には四条派が、東洞院丸太町には岸派が集中し、 二条両替町・御池衣棚・室町中立売には流派に関係なく集中寸る。 土佐派は寺町丸太町に居所を構える傾向があった、というように流 派による居住分布の傾向が存在することを前者によって伺える。

3)に関して、四条通以南に居所を構える絵師の割合は、『平安人物 志』天保 9 年版（1838）まで $10 \%$ を超えないが、『皇都書画人名録』 弘化 4 年版（1847）以降、15\%を超え、居住分布図と 2 つの視点か ら確認できる。

4)の内裏周辺における居住分布に関して、『平安人物志』天明 2 年版（1782）と『平安人物志』文化 10 年版（1813）の両版に収録さ れる 4 人の絵師のうち、岸派の岸駒と円山派の島田元直が内裏周辺 に移動し、かつこの 2 人は寛政度内裹造営に参加している。このよ うに、内裏造営に参加した絵師が内裏周辺に移動しており、文化以 降、多くの町絵師が内裹御用を勤めることに比例し、内裏周辺に居 所を構える絵師が増加することから、内裏造営への参加が絵師の居 住地に影響を与えた面があるのではないかと考えられる。これは西 陣・伏見など京都における居住地形成とは異なるあり方が、近世の 絵師居住の動向には確認できる、という意味で注目される。

5)に関して、文人画家の中には僧侶も含まれ、彼らが郊外に居所 を構えるのは、寺地が郊外に存在したためであるが、聖護院村や岡 崎村などには僧侶でない文人画家や町絵師が居所を構える。

\section{7. おわりに}

呉春の四条派、円山応挙の円山派、岸駒の岸派、原在中の原派、 さらに池大雅と与謝無村によって大成された文人画などの台頭によ り、近世京都画壇はまさに百花繚乱の時代であった。町絵師が幕府 の御用を勤めたことで、居住地形成に大きな変化をもたらした。朝 廷・幕府の御用を勤めることは、当時の絵師にとって、最大の関心 であり、かつ名誉であるといっても過言ではない。とすれば、彼ら の居所は依頼者の身分や地位、さらに居住地に左右されるのではな いかと考えられる。

並木氏は、『平安人物志』9版のなかで絵師の居住地についてはそ れほど大きな変化は見られない注 ${ }^{16)}$ と指摘している。だが、本稿で 明らかになったように、天明・文政・弘化において絵師の居住地に ついて、変化が看取された。さらに、流派による居住分布の傾向が 存在する可能性を得た。

本稿によって、近世京都における絵師の居所について、その一端 を垣間見ることができた。全貌解明のためには、流派による居住分 布の傾向や、当時の大火・地震・水害といった自然災害による影響 の検討も必要である。また、近世の郊外居所化と近代以降の郊外居 所化を、比較検討する必要もあるだろう。さらに、絵師の身分や社 会的地位などを踏まえて、居所は当時どのようなすがたをしていた のかなど、解明すべき残された課題は少なくない。
注 1）森銑三・中島理寿編『近世人名録集成』第一巻、勉誠社、1976 年所収。 他に、国際日本文化研究センターがウェブ上で公開している「平安人物 志データベース」があり、適宜参照した。

注 2）森銑三・中島理寿編『近世人名録集成』第四巻、勉誠社、1976 年所収。

注 3)『新修京都叢書』第六巻、光彩社、1968 年所収。

注 4）『新撰京都叢書』第二巻、臨川書店、1986 年所収。

注 5）『京の絵師は百花繚乱』京都文化博物館、1998 年において、『平安人物 志』に収録される絵師の分布地図が作成された（P. 316, 317,318）が、3 版をまとめた分布地図であり収録される絵師すべてを網羅していない。 本稿の分布地図は、居所が判明する絵師をすべて版ごとに反映させた。

注 6)『平安人物志』については、1970 年代に小笹喜三氏（小笹喜三編著、平 春生補稿『平安人物志 短冊集影』思文閣、1973 年)、竹林忠男氏 (『平 安人物志』およびその書家について、京都府立総合資料館『資料館紀要』 2 号、1973 年)、宗政五十緒氏（京都の文化社会一『平安人物志』化政 版と京都一（林屋辰三郎編『化政文化の研究』岩波書店、1976 年)）の 研究が存在する。

注 7）並木誠士「近代京都における画家の居所一中世から近代への展開」（研 究代表者中川理『郊外住宅地開発を導いた学術·芸術・芸能に関わる人々 の居住動向に関する歴史的研究一近代京都を事例として一』、2004 年)

注 8) 田島達也「『平安人物志』を読む」注 5 前掲。

注 9）武智正智による『平安人物志』人名録がウェブ上で公開されている。

注 10) 久保智康「京都の錺師たち」（『日本の美術 10 号、No. 437』至文堂、 2002 年)

注 11) 本稿では狩野派、土佐派、鶴沢派を御用絵師と呼ぶ。町絵師とは御用 絵師でない四条派、円山派、岸派、原派、望月派の絵師集団やどの流 派にも所属しない絵師のことを指す。

注 12）武田庸二郎「寛政度禁裏御所造営における絵師の選定について」(『近 世御用絵師の史的研究—幕藩制社会における絵師の身分と序列一』思 文閣、2008 年)

注 13）発行年順に表を作成し、左に収録される絵師の名前を、中央に絵師が 所属する流派を、右に居所を示した。名前の表記は、「『平安人物志』 に登場する画家一覧」（注 5 前掲）に従ったが、『京羽二重』、『皇都書 画人名録』、『京羽津根 (京羽洛津根)』では原文のまま用いたものもあ る。また、表 2-3、表 2-4に「望月玉仙」とあるが、原文は上段に「望 玉蟾」、下段に「望月与五郎」である。初代望月玉蟾は宝暦 3 年 (1753) もしくは同 5 年 (1755) に没しており、「画家解説」（注 5 前掲）にお いても、望月玉仙と判断されているので、本稿もそれに従った。同様 の事例が他にもあり適時、判断し表を作成した。流派を特定するにあ たり、「画家解説」、流派系図」(共に注 5 前掲) 、『日本書画名家辞典』 柏書房、1981 年、『辞典叢書 15 日本書画人名辞書』東出版、1996 年 を参照した。また、『皇都書画人名録』において、例えば、「○○先生 門人」と記載される絵師については、師匠の流派が判明している場合、 同じ流派とした。さらに、流派欄の表記については、「流派系図」（注 5 前掲）の表記に従い、「○○派」と「○○家」の二種類ある。名前の 右側に「*」がある絵師は文人画家であることを示す。『平安人物志』 において、明和 5 年版（1768）から天明 2 年版（1782）では文人画家 とそうでない絵師が一括して扱われており、文化 10 年版 (1813) では 上巻に登場する絵師が文人画家に相当し、文政 5 年版 (1822) 以降で は文人画家の項目がある。中央が空欄の絵師はどの流派にも所属しな い絵師であることを示す。居所が空欄である絵師は『平安人物志』、『皇 都書画人名録』、『京羽二重』、『京羽津根 (京洛羽津根)』において、不 記載であった。

注 14）算出方法は、「(ある通りに居所を構える絵師の人数）/ (収録数 $) \times$ $100(\%) 」 て ゙ あ る$ (小数点第 2 位を四捨五入)。この場合、『平安人物 志』天明 2 年版 (1782) の収録数は 29 人で、そのうち 3 人が四条堺町 から四条高倉に居所を構える。よって、その割合は「 $3 / 29 \times 100=10.3 \%$ 」 となる。以下、同様の手順で割合を算出した。

注 15）狩野山楽を祖とする京狩野派。

注 16）注 7 前掲。

（2009年11月10日原稿受理，2010年 5 月 6 日採用決定） 